ORIGINAL ARTICLE

\title{
SAND FLIES (DIPTERA: PSYCHODIDAE) IN AN ENDEMIC AREA OF LEISHMANIASIS IN AQUIDAUANA MUNICIPALITY, PANTANAL OF MATO GROSSO DO SUL, BRAZIL
}

\author{
Helen Rezende de FIGUEIREDO(1), Mirella Ferreira da Cunha SANTOS(2), Aline Etelvina CASARIL(1,3), Jucelei Oliveira de Moura INFRAN(3),
} Leticia Moraes RIBEIRO(3), Carlos Eurico dos Santos FERNANDES(4) \& Alessandra Gutierrez de OLIVEIRA(1,3)

\begin{abstract}
SUMMARY
The Aquidauana municipality is considered an endemic area of leishmaniasis and an important tourist site in Mato Grosso do Sul State. The aim of this study was to investigate the sand fly fauna in the city of Aquidauana. Captures were carried out twice a month, from April 2012 to March 2014 with automatic light traps and active aspiration, in the peridomicile and domicile of six residences. A total of 9,338 specimens were collected, 3,179 and 6,159 using light traps and active aspiration, respectively. The fauna consisted of: Brumptomyia brumpti, Evandromyia aldafalcaoae, Ev. evandroi, Ev. lenti, Ev. orcyi, Ev. sallesi, Ev. termitophila, Ev. walkeri, Lutzomyia longipalpis and Psathyromyia bigeniculata. The most abundant species captured was Lutzomyia longipalpis, present in all the ecotopes, predominantly in peridomicile areas, and mainly males. Leishmania DNA was not detected in the insects. It was observed the abundance of the sand fly fauna in the region, as well as the high frequency of Lu. longipalpis, the main vector of $L$. infantum. The results of this study show the need to increase the monitoring and more effective control measures. It is noteworthy that the studied region presents several activities related to tourism and recreation, increasing the risk of transmission of leishmaniasis to this particular human population.
\end{abstract}

KEYWORDS: Phlebotomine sand fly; Lutzomyia longipalpis; Fishing tourism.

\section{INTRODUCTION}

Sand flies (Diptera: Psychodidae: Phlebotominae) present medical importance because they are vectors of protozoans of the genus Leishmania, which are the etiological agents of leishmaniasis. These diseases are considered a major worldwide public health issue due to their high incidence and lethality rates ${ }^{1,2,3,4,5}$. In Mato Grosso do Sul State, leishmaniasis are rapidly expanding; cases of visceral leishmaniasis (VL) and cutaneous leishmaniasis (CL) have been reported in 56 and 72 municipalities, respectively ${ }^{6,7}$. In the municipality of Aquidauana, VL has been notified since 1998, with six cases reported ${ }^{8}$. From 1999 to 2011, 162 cases were registered; in 2013, seven cases were confirmed, and one death reported, and the city is now considered an area of intense VL transmission. Regarding CL, Aquidauana is an area of moderate transmission, with five confirmed rural cases in $2013^{7}$.

Approximately 900 species of sand flies are known worldwide. In Brazil, about 235 species have been reported ${ }^{9,10,11}$ and 66 of these were

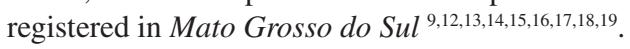

Sand flies are found in different climate conditions, in the wild, rural areas and often urban centers ${ }^{4,20,21,22}$. Therefore, studies regarding the fauna of these insects and their behavior are determinant aspects in the epidemiology of leishmaniasis. They are also of major importance in endemic areas as they provide basic information to design control measures of the disease by health services ${ }^{6,19,23,24,25,26}$.

Thus, this study aimed to investigate the fauna, as well as the distribution and the abundance of sand flies in the urban area of the municipality of Aquidauana, Mato Grosso do Sul State, Brazil.

\section{MATERIAL AND METHODS}

\section{Study Area}

The municipality of Aquidauana $\left(20^{\circ} 28^{\prime} 15^{\prime \prime} \mathrm{S}, 55^{\circ} 47^{\prime} 13^{\prime \prime} \mathrm{W}\right.$ and altitude of $149 \mathrm{~m}$ ) is located $139 \mathrm{~km}$ from the state capital, Campo Grande, in the western region of Mato Grosso do Sul ${ }^{27}$. According to the 2014 Brazilian Institute of Geography and Statistics ${ }^{28}$ census, the city

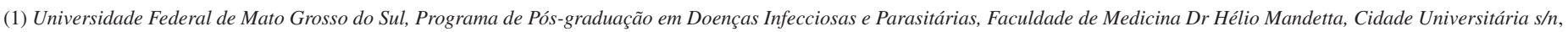
79070-900 Campo Grande, MS, Brazil. E-mails: helenrezende.bio@gmail.com; aline.casaril@gmail.com; alessandra.oliveira@ufms.br

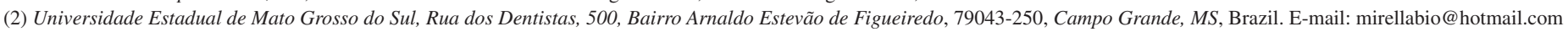

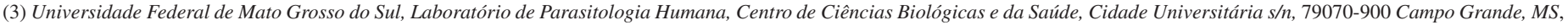
Brazil. E-mail: alessandra.oliveira@ufms.br; aline.casaril@gmail.com, juinfran@gmail.com

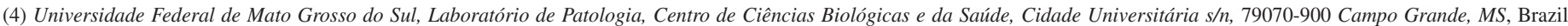
E-mail: carlos.fernandes@ufms.br

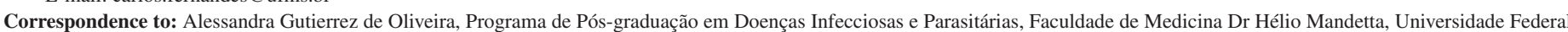
de Mato Grosso do Sul, Cidade Universitária s/n, 79070-900 Campo Grande, MS, Brazil. E-mail: alessandra.oliveira@ufms.br 


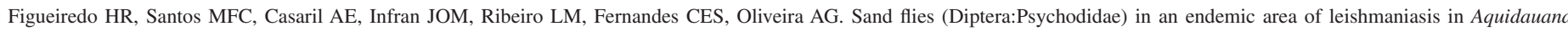
municipality, Pantanal of Mato Grosso do Sul, Brazil. Rev Inst Med Trop Sao Paulo. 2016;58:87.

population was 45,614 inhabitants. Aquidauana is situated at the edge of the plain area of the Pantanal biome. The city presents geomorphological characteristics of Maracajú plateau and the Aquidauana/ Bela Vista valley, forms the border of the territory. The river Aquidauana and the streams João Dias and Guanandy are located in the urban area of the municipality ${ }^{27}$. The climate, according to the Köppen Climate Classification System is AW, defined as a humid tropical climate. The daily temperature average starts to increase in August and reaches its peak in December ${ }^{29}$.

Six neighborhoods were selected, Bairro Alto, Pinheiro, São Francisco, São Cristovão, Guanandy and Paraíso (Fig. 1). In each of them, one residence was chosen to install two light traps, in both, the peridomicile and the domicile areas. The selection of neighborhoods followed the following criteria: notified cases of VL and/or CL human/ canine cases, together with the presence of domestic animals shelters such as kennels, hen houses and pig pens.
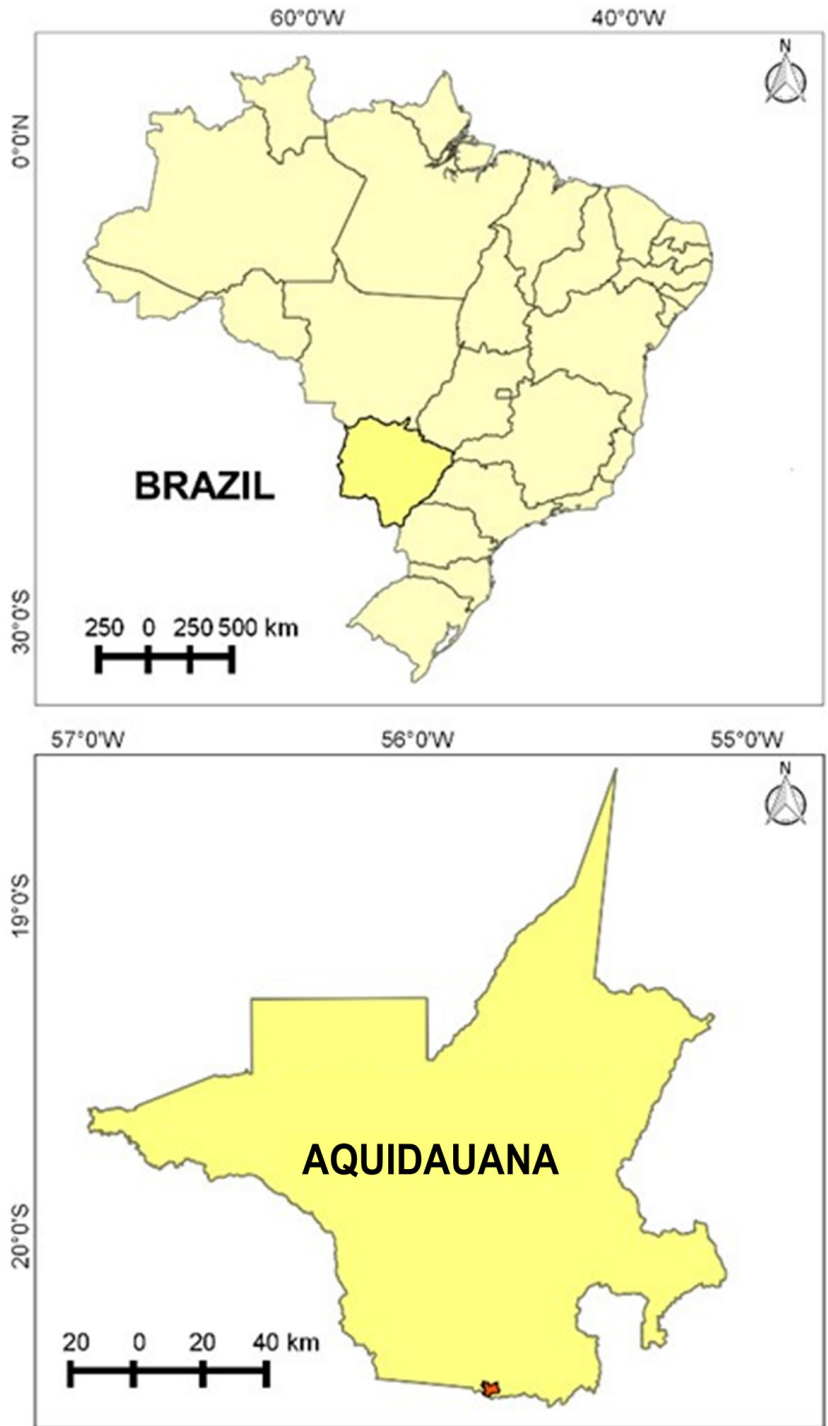

The selected residences, as well as the neighboring houses, had fruit trees in the backyards. Bairro Alto is located in the central region with no streams nearby. Pinheiro, São Cristovão, São Francisco, Guanandy and Paraíso are located in the outskirts of the city and are delimited by the streams João Dias and Guanandy. In these neighborhoods, the traps were installed about $200 \mathrm{~m}$ away from the remaining riparian forest, except for the selected residence in Guanandy, which also had a pig pen.

\section{Sand flies captures}

The collections were carried out twice a month with Falcão modified light traps placed both in the domicile and the peridomicile area of the selected residences, from April 2012 to March 2014. The captures were always conducted from $6 \mathrm{pm}$ to 7 am even during the period of daylight saving time. In order to increase the females sample size, captures were also performed by means of an electric mannual aspirator inside animal shelters in each of the selected residences. These collections began
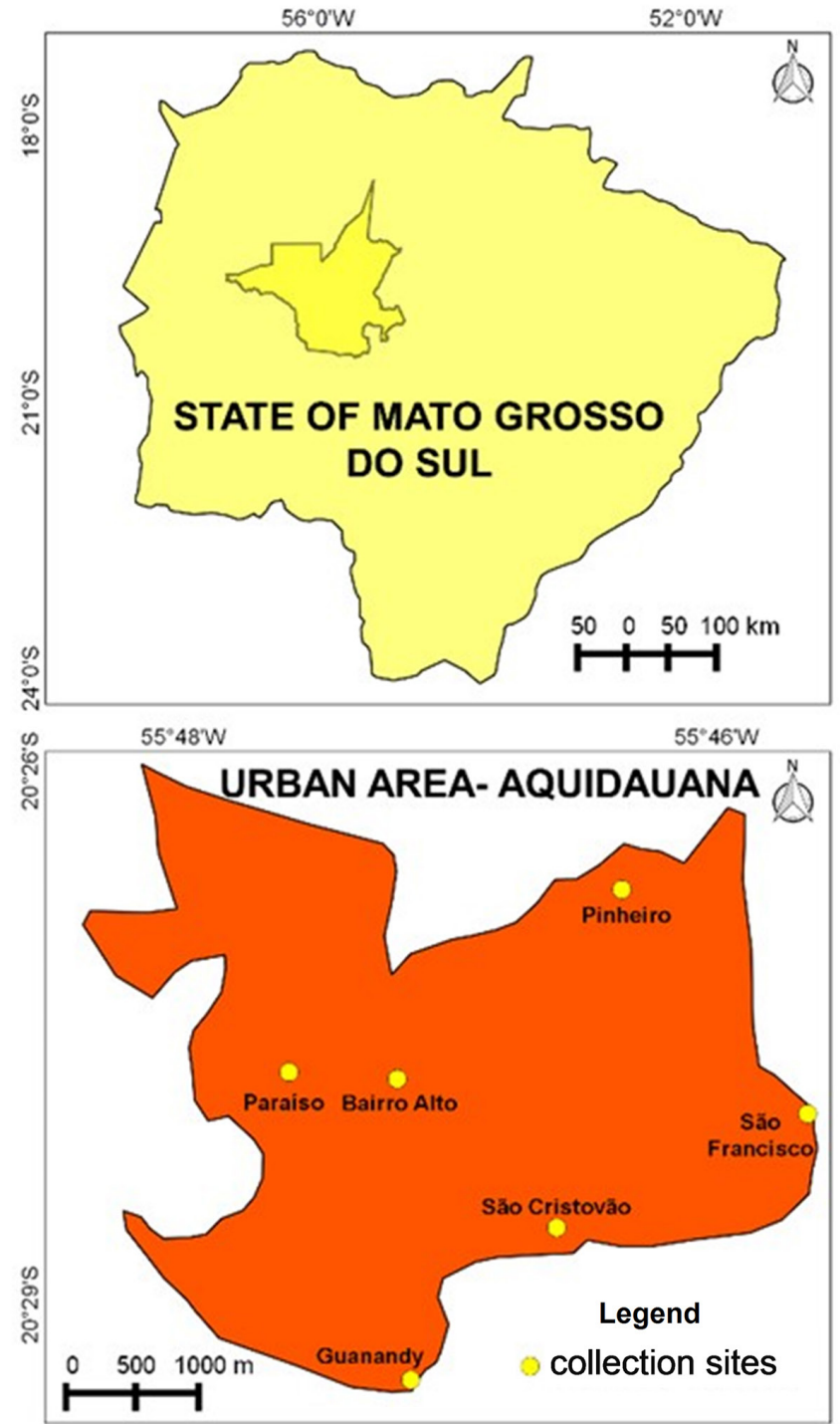

Fig. 1 - Study area and collection sites in the city of Aquidauana, Mato Grosso do Sul, Brazil, from 2012 to 2014. 


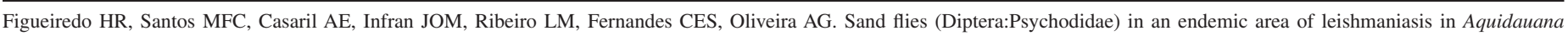
municipality, Pantanal of Mato Grosso do Sul, Brazil. Rev Inst Med Trop Sao Paulo. 2016;58:87.

in November 2012 and lasted 10-15 minutes. Captured insects were identified based on the classification described by Galati ${ }^{30}$ and genera abbreviations followed the recommendation of Marcondes ${ }^{31}$.

\section{Molecular analysis}

After identification, females were grouped in pools of up to 10 insects, according to species, location area and date of capture. Later, samples were sent to the Laboratory of Molecular Biology at the Federal University of Mato Grosso do Sul to investigate the presence of Leishmania spp. using the polymerase chain reaction (PCR) assay. DNA samples were extracted with 5\% Chelex® resin solution (Sigma-Aldrich, St. Louis, USA) and PCR was carried out according to the method of El Tai et $a l .^{32}$.

\section{Data analysis}

The Standardized Index of Species Abundance (SISA) was calculated to determine the most abundant species, according to the spatial distribution, for which 1.00 corresponds to the most abundant species $^{33}$. For the diversity analysis, the Shannon's diversity index $(\mathrm{H})^{34}$ was calculated and the measure of evenness or dominance of species was obtained using the Pielou's Index $(\mathrm{J})^{35}$. Dispersion data, symmetry and outliers were described by using the box plot graphic. The MannWhitney U-test was used to compare the male-female ratio between the peri and the intradomicile areas.

\section{RESULTS}

After 7,488 hours of collection using the light traps and 72 hours of collection using the active aspiration, 9,338 sand flies were captured, distributed among the genera: Brumptomyia, Evandromyia, Lutzomyia and Psathyromyia. The fauna comprised ten species: Brumptomyia brumpti (Larrousse, 1920), Evandromyia aldafalcaoae (Santos, AndradeFilho and Honer, 2001), Evandromyia evandroi (Costa Lima, 1932), Evandromyia lenti (Mangabeira, 1938), Evandromyia orcyi (Oliveira, Sanguinette, Almeida and Andrade Filho, 2015), Evandromyia sallesi (Galvão and Coutinho, 1939), Evandromyia termitophila (Martins, Falcão and Silva, 1964), Evandromyia walkeri (Newstead, 1914), Lutzomyia longipalpis (Lutz and Neiva, 1912) and Psathyromyia bigeniculata (Floch \& Abonnenc 1941).

Through the use of light traps, 3,179 specimens were captured, from which 2,780 (87.45\%) were males and 399 (12.55\%) were females. Table 1 shows the predominance of Lu. longipalpis, with 2,957 (93.02\%) specimens, followed by Evandromyia walkeri with 135 (4.25\%), Ev. aldafalcaoae with $31(0.98 \%)$ and others species totaling 56 specimens $(1.76 \%)$. Although eight out of the ten species reported in this study were captured in the Guanandy neighborhood with Shannon's diversity index of 0.6046, in São Francisco, where fewer species were caught, there was a higher Shannon's index of 1.3103 , with a Pielou equitability of 0.7312 (Table 1 ).

Lutzomyia longipalpis was the most abundant species (SISA $=1.00$ ), ranking first in the classification (Table 2). The species was captured in all the sampled areas, especially in the peridomicile, except for the São Francisco neighborhood (Fig. 2).

Evandromyia aldafalcaoae was the second most abundant species and presented a SISA $=0.95$, despite having fewer collected specimens compared to Ev. walkeri (SISA $=0.89$, the third in the ranking. $E v$. aldafalcaoae was more abundant in the neighborhood Pinheiro $(\mathrm{n}=21)$,

Table 1

Distribution of sandfly species captured with Falcão trap, according to neighborhoods, intradomicile and peridomicile, gender, Shannon's and Pielou's indexes per species in Aquidauana, Mato Grosso do Sul, Brazil, from April 2012 to March 2014 (n = 3179)

\begin{tabular}{|c|c|c|c|c|c|c|c|c|c|c|c|c|c|c|c|c|c|c|c|c|c|c|c|c|c|c|c|c|}
\hline \multirow{3}{*}{ Species } & \multicolumn{4}{|c|}{ Pinheiro } & \multicolumn{4}{|c|}{ São Francisco } & \multicolumn{4}{|c|}{ São Cristovão } & \multicolumn{4}{|c|}{ Guanandy } & \multicolumn{4}{|c|}{ Paraíso } & \multicolumn{4}{|c|}{ Bairro Alto } & \multicolumn{2}{|c|}{ Total } & \multicolumn{2}{|c|}{ Total } \\
\hline & \multicolumn{2}{|c|}{ Intra } & \multicolumn{2}{|c|}{ Peri } & \multicolumn{2}{|c|}{ Intra } & \multicolumn{2}{|c|}{ Peri } & \multicolumn{2}{|c|}{ Intra } & \multicolumn{2}{|c|}{ Peri } & \multicolumn{2}{|c|}{ Intra } & \multicolumn{2}{|c|}{ Peri } & \multicolumn{2}{|c|}{ Intra } & \multicolumn{2}{|c|}{ Peri } & \multicolumn{2}{|c|}{ Intra } & \multicolumn{2}{|l|}{ Peri } & \multirow[t]{2}{*}{ M } & \multirow[t]{2}{*}{$\mathrm{F}$} & \multirow[t]{2}{*}{$\mathrm{n}$} & \multirow[t]{2}{*}{$(\%)$} \\
\hline & $\mathrm{M}$ & $\mathrm{F}$ & $\mathrm{M}$ & $\mathrm{F}$ & $\mathrm{M}$ & $\mathrm{F}$ & M & $\mathrm{F}$ & $\mathrm{M}$ & $\mathrm{F}$ & M & $\mathrm{F}$ & $\mathrm{M}$ & $\mathrm{F}$ & $\mathrm{M}$ & $\mathrm{F}$ & $\mathrm{M}$ & $\mathrm{F}$ & $\mathrm{M}$ & $\mathrm{F}$ & $\mathrm{M}$ & $\mathrm{F}$ & $\mathrm{M}$ & $\mathrm{F}$ & & & & \\
\hline Br. brumpti & - & - & - & - & 1 & - & - & - & - & - & - & - & - & - & - & - & - & - & - & - & - & - & - & - & 1 & - & 1 & 0,03 \\
\hline Ev. aldafalcaoae & 3 & 3 & 12 & 3 & 1 & - & - & - & - & 2 & 1 & 2 & - & - & 1 & - & 2 & - & - & - & 1 & - & - & - & 21 & 10 & 31 & 0,98 \\
\hline Ev. evandroi & - & 1 & - & 1 & - & - & - & - & - & 1 & - & 1 & - & - & - & 8 & - & 2 & - & - & - & - & - & 1 & - & 15 & 15 & 0,47 \\
\hline Ev. lenti & 1 & - & - & - & - & - & - & - & - & - & - & - & - & - & 2 & - & - & 1 & - & - & - & - & - & - & 3 & 1 & 4 & 0,13 \\
\hline Ev. orcyi & - & - & - & - & - & - & - & - & - & - & - & - & - & 1 & 3 & 2 & - & - & - & - & - & - & - & - & 3 & 3 & 6 & 0,19 \\
\hline Ev. sallesi & - & - & - & - & - & - & - & - & - & - & - & 1 & - & 1 & 6 & 6 & - & - & - & - & - & - & - & - & 6 & 8 & 14 & 0,44 \\
\hline Ev. termitophila & - & - & - & - & - & - & 1 & - & - & - & - & - & - & - & - & - & - & - & - & - & - & - & - & - & 1 & - & 1 & 0,03 \\
\hline Ev. walkeri & - & - & - & - & 4 & - & 4 & 1 & 1 & - & - & - & 23 & - & 65 & 29 & - & - & 5 & - & 3 & - & - & - & 105 & 30 & 135 & 4,25 \\
\hline Lu. longipalpis & 90 & 15 & 670 & 72 & 4 & 1 & 3 & - & 278 & 41 & 522 & 62 & 12 & 2 & 688 & 75 & 1 & - & 45 & 4 & 116 & 25 & 202 & 29 & 2631 & 326 & 2957 & 93,02 \\
\hline Pa. bigeniculata & 2 & - & - & - & 1 & - & - & - & - & - & 1 & - & 3 & 2 & 2 & 3 & - & - & - & 1 & - & - & - & - & 9 & 6 & 15 & 0,47 \\
\hline Total & 96 & 19 & 682 & 76 & 11 & 1 & 8 & 1 & 279 & 44 & 524 & 66 & 38 & 6 & 767 & 123 & 3 & 3 & 50 & 5 & 120 & 25 & 202 & 30 & 2780 & 399 & 3179 & 100,00 \\
\hline $\begin{array}{l}\text { Shannon Diversity } \\
\text { Index }\end{array}$ & & & 530 & & & 1,3 & & & & 0.0 & 726 & & & & 046 & & & 0.7 & 257 & & & & 822 & & & & & \\
\hline Pielou Eveness Index & & 0.0 & 950 & & & 0.7 & & & & 0.0 & 405 & & & 0.2 & 907 & & & 0.4 & 509 & & & & 592 & & & & & \\
\hline
\end{tabular}

Intra: intradomicile; Peri: peridomicile; M: male; F: female; Br.: Brumptomyia; Ev.: Evandromyia; Lu.: Lutzomyia; Pa.: Psathyromyia. 


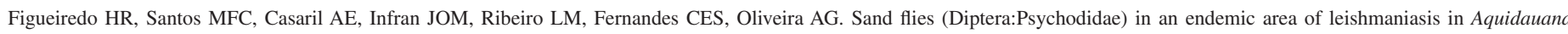
municipality, Pantanal of Mato Grosso do Sul, Brazil. Rev Inst Med Trop Sao Paulo. 2016;58:87.

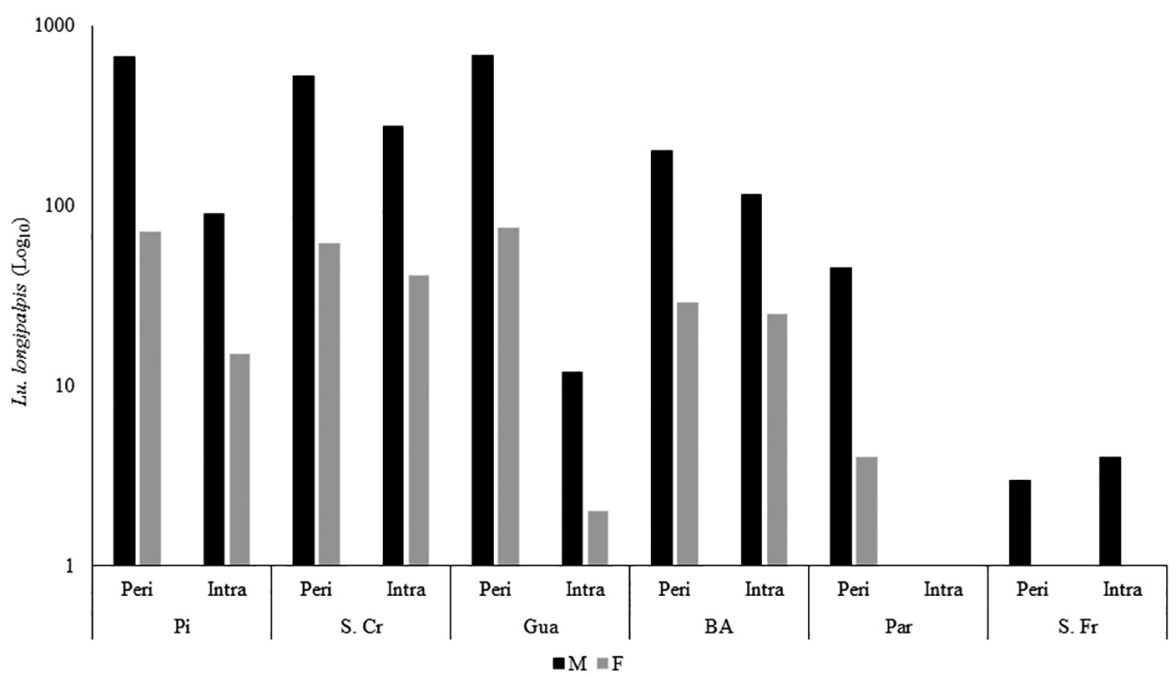

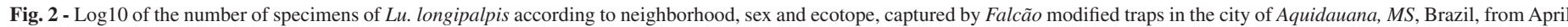

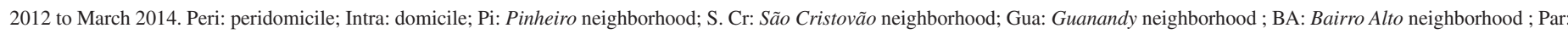
Paraíso neighborhood ; S. Fr: São Francisco neighborhood . M; male; F: female.

Table 2

Classification of the sandflies species captured with Falcão trap according to Standardized Index of Species Abundance (SISA) in Aquidauana, MS, from April 2012 to March 2014

\begin{tabular}{lcc}
\hline Species & Ranking & SISA \\
\hline Br. brumpti & $9^{\circ}$ & 0.02 \\
Ev. aldafalcaoae & $2^{\circ}$ & 0.95 \\
Ev. evandroi & $5^{\circ}$ & 0.83 \\
Ev. lenti & $7^{\circ}$ & 0.41 \\
Ev. orcyi & $8^{\circ}$ & 0.06 \\
Ev. sallesi & $6^{\circ}$ & 0.50 \\
Ev. termitophila & $9^{\circ}$ & 0.02 \\
Ev. walkeri & $3^{\circ}$ & 0.89 \\
Lu. longipalpis & $1^{\circ}$ & 1.00 \\
Pa. bigeniculata & $4^{\circ}$ & 0.85
\end{tabular}

Br.: Brumptomyia; Ev.: Evandromyia; Lu.: Lutzomyia; Pa.: Psathyromyia.

where a hen house was present in the peridomicile; while Ev. walkeri (n $=135$ ) had the highest number of individuals collected in the pig pen of the residence located in Guanandy. The species Ev. evandroi, Ev. lenti, Ev. sallesi, Pa. bigeniculata and Evandromyia orcyi were only slightly present (Table 2).

In total, both in the peridomicile and domicile areas, more males were captured than females, with a ratio of 6.97. Lu. longipalpis presented a ratio of 8.07 and Ev. walkeri 3.5. However, the species Ev. sallesi had more females than males, with a ratio of 0.75 and Ev. evandroi presented only females.

Figure 3 shows the male-to-female ratio of Lu. longipalpis correlating it to the peridomicile and domicile areas of the neighborhoods. Only in Guanandy, a statistically significant difference $(p=0.001)$ was observed between the two ecotopes.

\section{Aspiration}

Seven species totaling 6,159 specimens were collected, with 5,120 (83.13\%) males and 1,039 (16.87\%) females: Ev. aldafalcaoae, Ev. evandroi, Ev. sallesi, Ev. walkeri, Lu. longipalpis, Pa. bigeniculata and Ev. orcyi.

Table 3 describes the species captured in each ecotope and Table 4 shows their SISA. Lutzomyia longipalpis was the most frequent species $(97.68 \%)$ and was present in all the neighborhoods, ranking first (SISA =1.00). Evandromyia walkeri ranked second and Ev. sallesi ranked third. Other species accounted for $0.16 \%$ of the total.

The total male-to-female ratio was 4.9; 5.1 for $\mathrm{Lu}$. longipalpis and, on the contrary, Ev. sallesi presented a female predominance $(0.36)$ (Table 3). By analyzing the male-to-female ratio of Lu. longipalpis captured using light traps, there was a significant difference between the neighborhood Bairro Alto and the neighborhoods Guanandy, Paraíso and São Cristovão (Fig. 4).

From the total, $82.96 \%$ of the insects were caught in the neighbohoods of Guanandy, Bairro Alto and São Cristóvão (Fig. 5).

Comparing the peridomicile ecotopes, the pig pen located in Guanandy presented the highest yield and the greatest variety, with eight out of the ten species collected (Fig. 6 and Table 1).

\section{Leishmania DNA detection in the females}

No Leishmania DNA was detected in the 418 females sand flies assessed through the molecular analysis. 

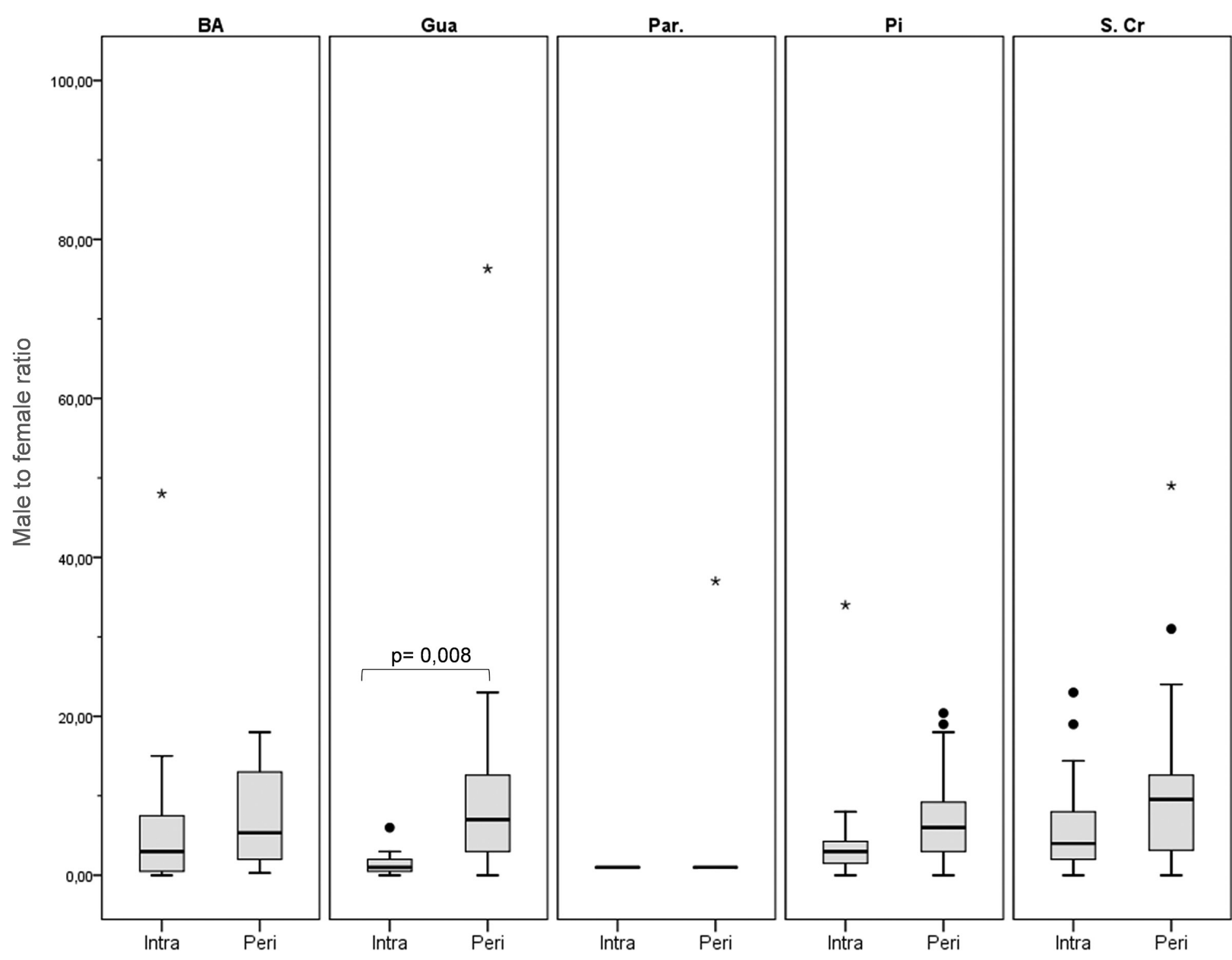

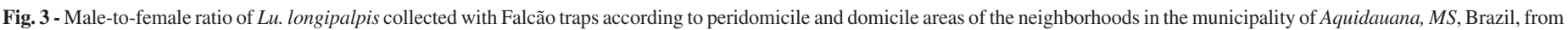

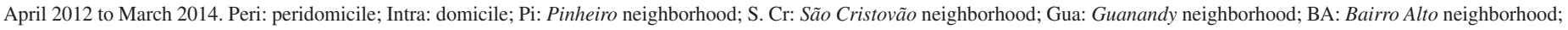
Par: Paraíso neighborhood; Asterisk and dot: outliers values; $p<0.05$ for statistically significant.

\section{DISCUSSION}

The epidemiology of leishmaniasis is complex and thus requires flexible control strategies suitable for each region and local occurrences. Therefore, knowledge about vectors is a fundamental tool to understand the transmission dynamics in order to plan preventive and control measures. This information is especially important in the city studied, where cases of visceral and cutaneous leishmaniasis are increasing. Considering that Aquidauana is a part of the Brazilian Pantanal and ecotourism tours and fishing activities are developed in this region of the state, the contact between vector and human population has been favored.

Several methods of sand flies capture have been used, but among these, light traps stand out and are widely used in fauna studies, as they are easy to use and inexpensive; although they may interfere in both the quality and the quantity of specimens collected ${ }^{36,37,38}$. On the other hand, by standardizing the collections for fortnightly captures during two consecutive years, associated with another capture technique, it was possible to increase the number of specimens collected, providing data to understand the behavior of the species present in the urban area of the city.
Considering the limitations of this type of capture, active aspiration was also performed in order to increase the number of captured females to investigate the presence of flagellates. After analyzing the performance of the two techniques, it was observed that the aspiration obtained the highest number of insects in less time gathering (72 h). In contrast, in 7,488 hours, light traps captured fewer specimens, but presented more variety. This amount could be explained by the dynamics of the capture technique; while the sand fly is attracted by light and host in one method, by in the other, the collection is active, and did not give the insect a chance to choose.

The wider variety of species observed in light traps collection has already been reported by other authors ${ }^{15,16,38,39,40,41,42,43}$. Actually, this high diversity has also been demonstrated in other municipalities located in the Pantanal. Casaril et al. ${ }^{26}$ found 12 species in a total of 7,370 specimens in the city of Corumbá, MS. In Cáceres, state of Mato Grosso, despite the lower frequency of insects, 28 different species were observed ${ }^{44}$. In Aquidauana, during the study period, ten species of sand flies were captured in a total of 9,338 individuals, differing from a previous study, 


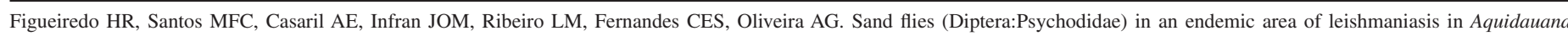
municipality, Pantanal of Mato Grosso do Sul, Brazil. Rev Inst Med Trop Sao Paulo. 2016;58:87.

Table 4

Classification of the sandflies species captured using aspiration according to Standardized Index of Species Abundance (SISA) in Aquidauana, MS, from April 2012 to March 2014

\begin{tabular}{lcc}
\hline Species & Ranking & SISA \\
\hline Ev. aldafalcaoae & $6^{\circ}$ & 0.07 \\
Ev. evandroi & $4^{\circ}$ & 0.21 \\
Ev. orcyi & $5^{\circ}$ & 0.09 \\
Ev. sallesi & $3^{\circ}$ & 0.30 \\
Ev. walkeri & $2^{\text {o }}$ & 0.33 \\
Lu. longipalpis & $1^{\circ}$ & 1.00 \\
Pa. bigeniculata & $7^{\circ}$ & 0.04
\end{tabular}

Br.: Brumptomyia; Ev.: Evandromyia; Lu.: Lutzomyia; Pa.: Psathyromyia.

conducted between 2003 and $2005^{13}$, when 16 species were reported and ten of them were different from the ones captured in the present study.

It is known that changes in the environment caused by human action, such as road construction, deforestation, fires, migration and mining can modify some aspects of the sand flies' ecology, leading to modifications of the local fauna ${ }^{45,46,47,48}$. These changes were noted in Aquidauana during the studied period, and have possibly interfered with the sand fly fauna of the municipality. The fact that some species can adapt to changes occurred in their environment, while others have their frequency decreased or even disappear is already known ${ }^{22,26}$. Furthermore, both the collection sites and the methodology used in the study of Almeida et al. ${ }^{13}$ were different from those used in the present study. In this work, the collections were systematized and performed twice a month during two consecutive years. These protocol particularities may explain the differences between both studies regarding the species found.
The four most abundant species in this study were Lu. longipalpis, which had the highest number of individuals captured in both techniques used, followed by Ev. aldafacaoae, Ev. walkeri and Ev. sallesi.

An increased frequency of $L u$. longipalpis was noted when compared to data reported by Almeida et al. ${ }^{13}$. It is known that the ability of a species to adapt to an environment can be influenced by environmental conditions, abiotic factors, food supply and interspecific competitive interactions $\mathrm{s}^{49,50}$, therefore $\mathrm{Lu}$. longipalpis could be exerting a greater selective pressure over the local species ${ }^{47,49,50,51}$, besides that, this species seems to be more anthropized $^{17,18,19,48,52,53,54,55,56,57,58}$.

The urbanization of the vector strongly indicates its anthropophilic behavior and points out its important role in local transmission of the parasite, since Aquidauana is considered an area of intense VL transmission ${ }^{7}$. Previous studies have demonstrated the association of a high frequency of Lu. longipalpis in higher prevalence regions $6,54,59,60,61$. This fact reinforces the species' importance of connecting the transmission to the etiological agent.

The species Ev. aldafalcaoae was found in all the ecotypes, and appears in second place in the ranking of the most abundant species. A higher frequency of this species was observed in Pinheiro neighborhood. Aquidauana is the type locality of this species' male ${ }^{62}$. Ev. aldafalcaoae has already been reported in other regions of Pantanal, such as Corumbá ${ }^{26}$, Nhecolândia ${ }^{63}$ and Caceres in Mato Grosso ${ }^{40}$. In addition to these locations, Dorval et al. ${ }^{64}$ found a single male in the domicile of a residence in Bela Vista, Mato Grosso do Sul.

Evandromyia walkeri was the third most abundant species however this species ranked second in the active aspiration. Although it has been reported in areas of forest and woods ${ }^{65,66,67,68}$, this species was captured in the peridomicile and domicile of almost all the sampled sites. The highest number of Ev. walkeri specimens was collected in the neighborhood of Guanandy, a fact that could be explained by the proximity of this location

Table 3

Distribution of sandfly species captured using aspiration in peridomicile according to neighborhoods and gender in Aquidauana, Mato Grosso do Sul, Brazil, from April 2012 to March $2014(\mathrm{n}=6159)$

\begin{tabular}{|c|c|c|c|c|c|c|c|c|c|c|c|c|c|c|c|c|}
\hline \multirow{2}{*}{ Species } & \multicolumn{2}{|c|}{ Pinheiro } & \multicolumn{2}{|c|}{ São Francisco } & \multicolumn{2}{|c|}{ São Cristovão } & \multicolumn{2}{|c|}{ Guanandy } & \multicolumn{2}{|c|}{ Paraíso } & \multicolumn{2}{|c|}{ Bairro Alto } & \multicolumn{2}{|c|}{ Total } & \multicolumn{2}{|c|}{ Total } \\
\hline & M & $\mathrm{F}$ & M & $\mathrm{F}$ & M & $\mathrm{F}$ & M & $\mathrm{F}$ & M & $\mathrm{F}$ & M & $\mathrm{F}$ & & & & \\
\hline Ev. aldafalcaoae & - & - & - & - & - & - & - & 2 & - & - & - & - & - & 2 & 2 & 0,03 \\
\hline Ev. evandroi & - & - & - & - & - & 2 & - & - & - & - & - & 1 & - & 3 & 3 & 0,05 \\
\hline Ev. orcyi & - & - & - & - & - & - & - & 4 & - & - & - & - & - & 4 & 4 & 0,06 \\
\hline Ev. sallesi & - & - & - & - & - & 5 & 16 & 39 & - & - & - & - & 16 & 44 & 60 & 0,97 \\
\hline Ev. walkeri & - & - & - & - & 3 & - & 66 & 4 & - & - & - & - & 69 & 4 & 73 & 1,19 \\
\hline Lu. longipalpis & 578 & 145 & 18 & 1 & 1375 & 110 & 1374 & 497 & 155 & 7 & 1534 & 222 & 5034 & 982 & 6016 & 97,68 \\
\hline Pa. bigeniculata & - & - & - & - & - & - & 1 & - & - & - & - & - & 1 & - & 1 & 0,02 \\
\hline Total & 578 & 145 & 18 & 1 & 1378 & 117 & 1457 & 546 & 155 & 7 & 1534 & 223 & 5120 & 1039 & 6159 & 100,00 \\
\hline $\begin{array}{l}\text { Índice de Diversidade de } \\
\text { Shannon }(\mathrm{H})\end{array}$ & & & \multicolumn{2}{|c|}{0.0000} & \multicolumn{2}{|c|}{0.0464} & \multicolumn{2}{|c|}{0.3060} & \multicolumn{2}{|c|}{0.0000} & \multicolumn{2}{|c|}{0.0043} & & & & \\
\hline Equitabilidade de Pielou (J) & & & \multicolumn{2}{|c|}{0.0000} & \multicolumn{2}{|c|}{0.0334} & \multicolumn{2}{|c|}{0.1707} & \multicolumn{2}{|c|}{0.0000} & \multicolumn{2}{|c|}{0.0062} & & & & \\
\hline
\end{tabular}

Peri: peridomicile; M: male; F: female; Br.: Brumptomyia; Ev.: Evandromyia; Lu.: Lutzomyia; Pa.: Psathyromyia. 


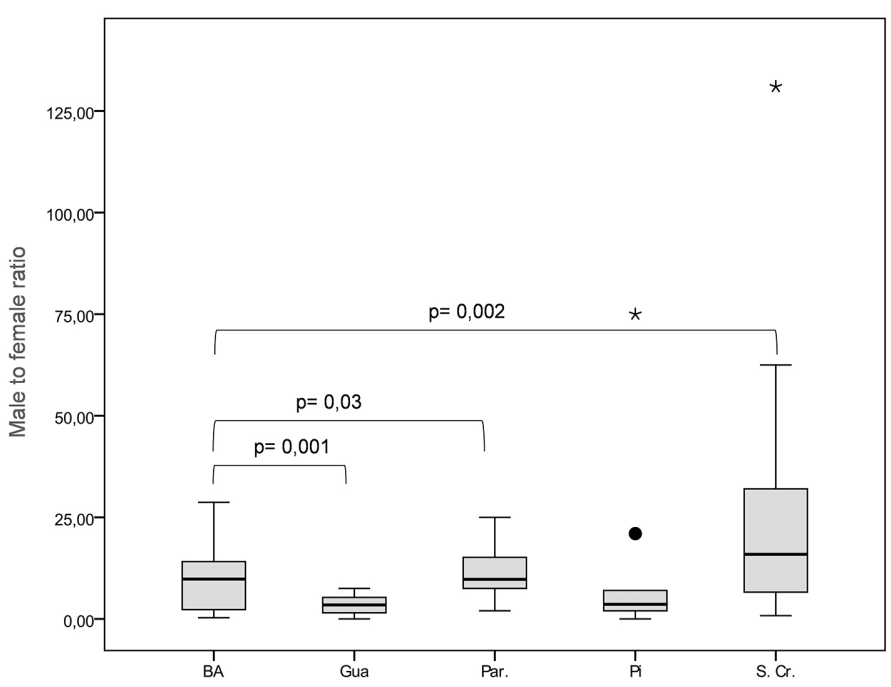

Fig. 4 - Male-to-female ratio of Lu. longipalpis collected by aspiration, in the peridomicile of the neighborhoods in the municipality of Aquidauana, MS, from November 2012 to March 2014. Pi: Pinheiro neighborhood; S. Cr: São Cristovão neighborhood; Gua: Guanandy neighborhood; BA: Bairro Alto neighborhood; Par: Paraíso neighborhood; Asterisk and dot: outliers values; $p<0.05$ for statistically significant. From the insects' total, $82.96 \%$ were captured in the following neighborhoods: Guanandy, Bairro Alto and São Cristóvão (Fig. 5).

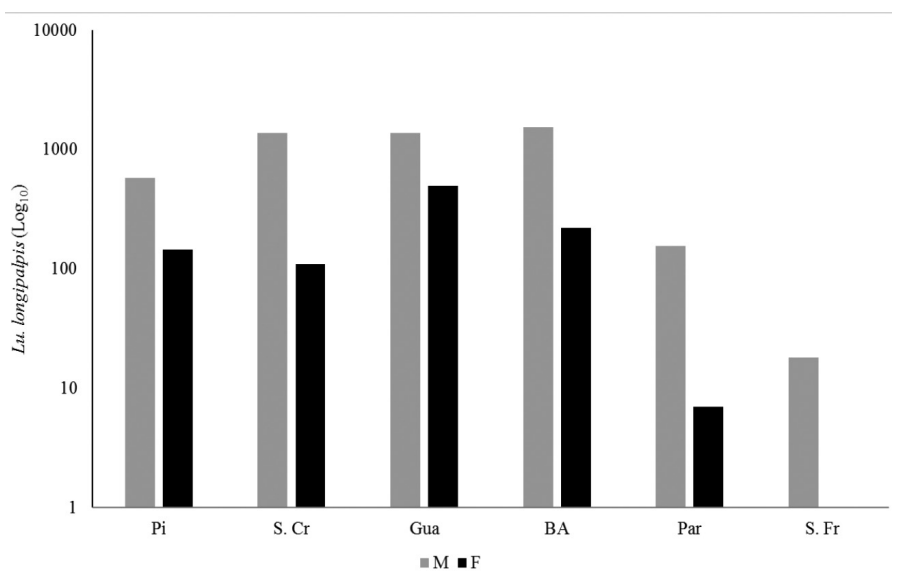

Fig. 5 - Number of specimens of Lu. longipalpis in $\log _{10}$, collected by aspiration, according to neighborhood and sex in the municipality of Aquidauana, MS, from November 2012 to March 2014. Pi: Pinheiro neighborhood; S. Cr: São Cristovão neighborhood; Gua: Guanandy neighborhood; BA: Bairro Alto neighborhood; Par: Paraíso neighborhood; S. Fr: São Francisco neighborhood; M: male; F: female.

to the insect's natural habitat. This neighborhood is inserted into a riparian area of the Guanandy stream, and it is located about 100 meters away from the confluence with the Aquidauana river. The presence of Ev. walkeri at various sites in the city, even in small numbers, indicates an adaptation process to the urban and anthropic environment, considering that Aquidauana is in expansion process and natural ecotypes are decreasing.

It is highly important to know the behavior of Ev. walkeri, as it has been found naturally infected by Leishmania (Viannia) spp. ${ }^{69}$. Its participation in the transmission of CL agents has not yet been proven, but it is believed that this species may be involved in the epidemiological chain of the disease in agroforestry environments ${ }^{69}$.

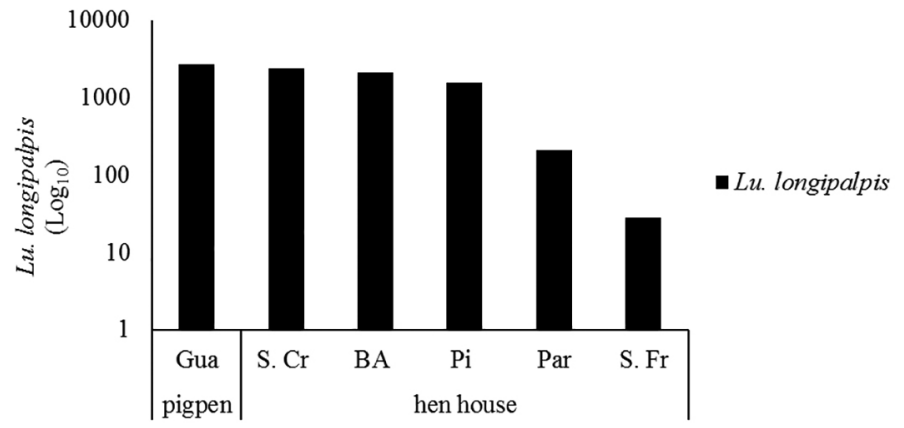

Fig. 6 - Absolute number in $\log _{10}$ of Lu. longipalpis, according to ecotopes and neighborhoods in the municipality of Aquidauana, MS, from April 2012 to March 2014. Pi: Pinheiro neighborhood; S. Cr: São Cristovão neighborhood; Gua: Guanandy neighborhood; BA: Bairro Alto neighborhood; Par: Paraíso neighborhood; S. Fr: São Francisco neighborhood.

Captures made by aspiration reflected a different pattern regarding the abundance index. The ranking of species had Lu. longipalpis in first place and a variation between Ev. walkeri and Ev. sallesi. Despite being in third place, Evandromyia sallesi presented a low yield in the collection, fact that was also reported by Nunes et al. ${ }^{54}$ in the municipality of Bonito, which borders the Aquidauana municipality, where a sporadic low density presence of this species was reported. Although there is no report of anthropophilic behavior, DNA from L. infantum ${ }^{70}$ has been found in this species, enhancing its epidemiological significance.

The Guanandy neighborhood had the highest number of specimens and variety of species caught (eight out of ten) in both techniques of capture; however this site showed a predominance of Lu. longipalpis, therefore Pielou's and Shannon's indexes of this neighborhood occupied the third place among the sampled ecotopes, a tendency that has also been observed in other studies performed in the state ${ }^{54,22}$. On the other hand, the São Francisco neighborhood was the ecotope where the highest abundance and evenness indexes of species caught through light trap was registered. Despite the low frequency in capture and the presence of only seven of the ten species collected in the city, it appears that species are in equilibrium in this site, without the predominance of one of them. Guanandy is located in the outskirts of the city, therefore its surroundings presented rural characteristics, including the presence of synanthropic animals near the residences according to the residents.

The second lowest Shannon's index was observed in the Bairro Alto neighborhood, situated downtown in the city. This result was similar to data reported by Oliveira et al. ${ }^{22}$ in Campo Grande. In general, central areas of cities have modified environments caused by human action; most terrain features constructions and vegetal biomass are reduced, which probably disfavors the presence of several species of sand flies. However, species able to adapt to these modified environments demonstrate an anthropophilic tendency and the possibility of transmitting pathogens ${ }^{22,58,71,72,73,74}$.

Regarding the sex ratio, irrespective of the type of capture, a predominance of males compared to females was noted. The male-tofemale ratio of $\mathrm{Lu}$. longipalpis was 8.07:1 using light traps and 5.1:1 through manual aspiration. Comparing both capture methods, a higher yield of females was observed in aspiration, as there was a decline of 


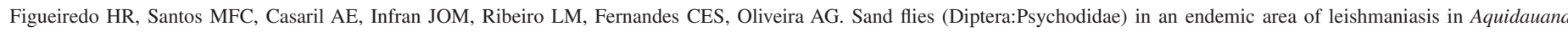
municipality, Pantanal of Mato Grosso do Sul, Brazil. Rev Inst Med Trop Sao Paulo. 2016;58:87.

the male-to-female ratio. Ximenes et al. ${ }^{38}$ observed a ratio of 18.26 and 4.62 using light traps and manual aspiration, respectively.

Through the use of light traps, it was observed that, comparing male-to-female ratios of peridomicile and domicile areas, only the Guanandy neighborhood showed no significant differences among the ecotopes. The domicile presented a greater equilibrium between males and females, probably due to the presence of dogs living inside the houses, which may have contributed to the encounter of more females in this environment ${ }^{52,75,76,77}$. Other authors have previously reported differences among the peridomicile and domicile ratios, however a higher proportion of males in all the ecotypes was reported ${ }^{6,13}$.

The predominance of males is unanimous, even in studies performed in the state, like Bonito with a ratio of $5.7^{54}$, Ponta Porã with $4.8^{13}$ and 2.95 in Campo Grande ${ }^{19}$. This behavior may also have been influenced by the males characteristics related to hatching before females ${ }^{14,19,36,78}$.

Moreover, the observed predominance can be explained by the lekking behavior described for Lu. longipalpis ${ }^{79,80,81,82}$ in which males are attracted by kairomones released by the hosts, leading the males to release pheromones that attract females ${ }^{83,84,85}$, providing an environment where sand flies can copulate, and females can feed in animals. Because of the weight of the females after feeding, they could seek refuge in shelters with less luminosity to perform digestion, thus becoming less attracted to the traps ${ }^{80}$. It is possible that the presence of large amounts of males and the attraction of females close to a host is an adaptive process to increase reproductive success of the species ${ }^{38,79,81}$.

Regarding the peridomicile and domicile environments, a significant difference was noted between them. The peridomicile was the ecotope with greater quantity and diversity of species, except for the São Francisco neighborhood, where the total amount of insects collected was so low that it was impossible to infer on this behavior. Another neighborhood that showed a large quantity of insects in the domicile was São Cristovão. It is important to note the proximity of this site to the hen house, since the house wall bordered the enclosure of the hen.

Other studies that reported a higher yielding of Lu. longipalpis in the domicile suggested that this behavior may be possible related to unfavorable weather conditions, lack of hosts in the peridomicile, and in some cases the presence of domestic animals living inside the houses, which highlights their endophilic capacity and the possibility of increasing the parasite transmission in this environment ${ }^{39,86,87}$.

Therefore, the greater number of specimens captured in the peridomicile is probably related to the presence of animals. This behavior, as described in several other reports, shows the sand flies' preference for environments with the presence of domestic or farmed animals $^{52,54,88,89,90,91,92,93,94}$. Actually, some authors emphasize the insects' preference for farmed animals with respect to animals in natural habitats ${ }^{95,96}$.

Regarding the Lu. longipalpis feeding habits, several studies reported the eclectic habit of this species ${ }^{45,48,75,76,97,98}$, however Morrison et al. ${ }^{99}$ suggested that it may act as an opportunist and feed on the closest animals to its breeding site. A higher attraction for birds, especially chickens, and dogs have also been demonstrated ${ }^{19,52,75,76,98}$. Other domestic mammals such as cats, equines, goats, cattle and swine have also been evidenced as part of these insects $\operatorname{diet}^{52,75,76,95,98}$.

The pig pen was an environment where the amount of collected insects was very significant. This result is consistent with the studies of Galati et al. ${ }^{15}$ and Carvalho et al. ${ }^{100}$ who have also observed a greater attractiveness of sand flies in this ecotope. It can be noted that the presence of large amounts of organic matter, produced by feces and food scraps in precarious hygienic environments, in addition to the shading of the area by a remnant of riparian vegetation, were probably important to create and maintain the insects at this site. This can be justified by other studies that have already shown the presence of organic matter as a predisposal factor to the finding of these insects in environments with such characteristics ${ }^{91,93,94,100}$. Alexander et al. ${ }^{88}$ reported other factors that could influence the attractiveness by different host species that must be considered, such as the biomass difference, heat loss, $\mathrm{CO} 2$ production and the odor released by the animal, besides blood $\mathrm{n}$ utritional value.

According to Gomes ${ }^{51}$, this eclectic behavior is a precondition for the ability of a species to evolve to synanthropy. In domiciliation for example, the species tendency of using humans or domestic animals as food supply and artificial ecotopes as shelters is clear. This fact evidences the survivability of species after the destruction of their natural ecotopes.

Additional studies on feeding habits and breeding sites of sand flies are certainly needed for a better understanding of leishmaniasis transmission cycle in the municipality.

In the present study, no sand fly was detected naturally infected with Leishmania in a total of 418 females analyzed by PCR. This result corroborates those from Souza et $a l .^{92}$, who found no positivity among 318 samples. In several studies, the occurrence of natural infection caused by Leishmania among sand fly populations has been described as low. In Brazil, the infection estimated rates were $0.4 \%$ in Bahia and Maranhão $o^{101,102}, 0.7 \%$ in Mato Grosso ${ }^{103}, 0.9 \%$ in Minas Gerais $^{100}, 1.1 \%$ in Corumbá ${ }^{104}$ and $2 \%$ in Rio de Janeiro ${ }^{105}$.

Infection rates can be influenced by vectors' ecological factors such as intraspecific behaviors, diet and host population of each region. The selection of the molecular technique employed can also influence these rates, as it may lead to lower rates of natural infection ${ }^{32,105,106,107,108}$.

In the municipality of Aquidauana, the maintenance of leishmaniasis, especially VL is likely to be related to the high prevalence of canine infection, as only in the year 2013, 1,666 dogs were diagnosed and 883 were euthanized, among suspected and confirmed cases ${ }^{109}$.

In the present study, it was possible to observe the sand flies adaptation to the urban area of the municipality of Aquidauana, which was confirmed by the presence of several species both in the peridomicile and the domicile of all the ecotypes. The abundance of sand fly fauna in the region and the high frequency of Lu. longipalpis, a $L$. infantum vector, was noted, demonstrating the need to intensify the monitoring and to stablish more efficient control measures. It is noteworthy that the studied region is involved in several recreational activities, thus representing an even greater risk factor for the transmission of leishmaniasis. 
Figueiredo HR, Santos MFC, Casaril AE, Infran JOM, Ribeiro LM, Fernandes CES, Oliveira AG. Sand flies (Diptera:Psychodidae) in an endemic area of leishmaniasis in Aquidauana municipality, Pantanal of Mato Grosso do Sul, Brazil. Rev Inst Med Trop Sao Paulo. 2016;58:87.

\section{CONFLIT OF INTEREST}

The authors declare that there are no conflicts of interest.

\section{ACKNOWLEDGMENTS}

We are grateful to the Controle de Vetores, to the residents of the municipality of Aquidauana; to Kezia Oliveira Kawasaki (PIBIC-Junior), the whole lab team of human parasitology and the Brazilian agency CAPES as well as the FUNDECT/SUCITEC/SEMAC N ${ }^{\circ}$ 09/2012 BIOTA-MS for their financial support.

\section{REFERENCES}

1. Brasil. Ministério da Saúde. Secretaria de Vigilância em Saúde. Departamento de Vigilância Epidemiológica. Manual de vigilância e controle da leishmaniose visceral. Brasília: Ministério da Saúde; 2006.

2. Brasil. Ministério da Saúde. Secretaria de Vigilância em Saúde. Departamento de Vigilância Epidemiológica. Leishmaniose visceral: recomendações clínicas para redução da letalidade. Brasília: Ministério da Saúde; 2011

3. Desjeux P. Leishmaniasis: current situation and new perspectives. Comp Immunol Microbiol Infect Dis. 2004;27:305-18

4. Dantas-Torres F, Brandão-Filho SP. Visceral leishmaniasis in Brazil: revisiting paradigms of epidemiology ando control. Rev Inst Med Trop Sao Paulo. 2006;48:151 6.

5. Gontijo B, Carvalho MLR. Leishmaniose tegumentar americana. Rev Soc Bras Med Trop. 2003;36:71-80

6. Oliveira GMG, Figueiró-Filho EA, Andrade GMC, Araújo LA, Oliveira MLG, Cunha RV. Flebotomíneos (Diptera: Psychodidae: Phlebotominae) no município de Três Lagoas, área de transmissão intensa de leishmaniose visceral, Estado de Mato Grosso do Sul, Brasil. Rev Pan-Amaz Saude. 2010;1:83-94.

7. Secretaria de Saúde do Estado de Mato Grosso do Sul. Relatório de notificações de leishmaniose visceral humana. Campo Grande: Governo do Estado de Mato Grosso do Sul; 2013.

8. Antonialli SAC, Torres TG, Paranhos-Filho AC, Tolezano JE. Spatial analysis of American Visceral Leishmaniasis in Mato Grosso do Sul State, Central Brazil. J Infect. 2007;54:509-14.

9. Galati EAB, Nunes VLB, Boggiani PC, Dorval MEC, Cristaldo G, Rocha HC, et al Phlebotomines (Diptera, Psychodidae) in caves of the Serra da Bodoquena, Mato Grosso do Sul State, Brazil. Rev Bras Entomol. 2003a;47:283-96.

10. Ready PD. Biology of Phlebotomine sand flies as vectors of disease agents. Annu Rev Entomol. 2013;58:227-50.

11. Souza CF, Borges MA, Andrade AJ. Contribution to the knowledge of the phlebotomine sand flies fauna (Diptera: Psychodidae) of Timóteo municipality, Minas Gerais, Brazil. Neotrop Entomol. 2009;38:267-71.

12. Andrade AR, Nunes VLB, Galati EAB, Arruda CCP, Santos MFC, Rocca MEG, et al. Estudo epidemiológico das leishmanioses em área de turismo ambiental e ecoturismo, Estado de Mato Grosso do Sul, 2006-2007. Rev Soc Bras Med Trop. 2009; 42:488-93.

13. Almeida PS, Nascimento JC, Ferreira AD, Minzão LD, Portes F, Miranda AM, et al. Espécies de flebotomíneos (Diptera, Psychodidae) coletadas em ambiente urbano em municípios com transmissão de leishmaniose visceral do Estado de Mato Grosso do Sul, Brasil. Rev Bras Entomol. 2010;54:304-10.
14. Galati EAB, Nunes VLB, Dorval MEC, Oshiro ET, Cristaldo G, Espíndola MA, et al Estudo dos flebotomíneos (Diptera, Pychodidae), em área de leishmaniose tegumentar, no Estado de Mato Grosso do Sul, Brasil. Rev Saude Publica. 1996; 30:115-28.

15. Galati EAB, Nunes VLB, Cristaldo G, Rocha HC, Oshiro ET. Aspectos do comportamento da fauna flebotomínea (Diptera: Psychodidae) em foco de leishmaniose visceral e tegumentar na Serra da Bodoquena e área adjacente, Estado de Mato Grosso do Sul, Brasil. Rev Patol Trop. 2003b;32:235-61.

16. Galati EAB, Nunes VLB, Boggiani PC, Dorval MEC, Cristaldo G, Rocha HC, et al. Phlebotomines (Diptera: Psychodidae) in forested areas of the Serra da Bodoquena, state of Mato Grosso do Sul, Brazil. Mem Inst Oswaldo Cruz. 2006;101:175-93.

17. Oliveira AG, Falcão AL, Brazil RP. Primeiro encontro de Lutzomyia longipalpis (Lutz \& Neiva, 1912) na área urbana de Campo Grande, MS, Brasil. Rev Saude Publica. 2000;34:654-55

18. Oliveira AG, Andrade-Filho JD, Falcão AL, Brazil RPA. New Sand Fly, Lutzomyia campograndensis sp. $\mathrm{n}$. (Diptera: Psychodidae: Phlebotominae) from the State of Mato Grosso do Sul, Brazil. Mem Inst. Oswaldo Cruz. 2001;96:325-9.

19. Oliveira AG, Galati EAB, Fernandes CE, Dorval MEC, Brazil RP. Ecological aspects of phlebotomines (Diptera: Psycodidae) in endemic area of visceral leishmaniasis, Campo Grande, State of Mato Grosso do Sul, Brazil. J Med Entomol. 2012a;49:43-50.

20. Andrade-Filho JD, Carneiro APS, Lima MLN, Santiago RM, Gama MA, Santos CA, et al. Flebotomíneos de Timóteo, Estado de Minas Gerais, Brasil (Diptera: Psychodidae). Cad Saude Publica. 1997;13:767-70.

21. Andrade AJ, Dantas-Torres F. Phlebotomine sand flies (Diptera: Psychodidae) of the state of Minas Gerais, Brazil. Neotrop Entomol. 2010;39:115-23.

22. Oliveira AG, Galati EAB, Oliveira O, Oliveira GR, Espindola IAC, Dorval MEC, et al. Abundance of Lutzomyia longipalpis (Diptera: Psychodidae: Phlebotominae) and urban transmission of visceral leishmaniasis in Campo Grande, state of Mato Grosso do Sul, Brazil. Mem Inst Oswaldo Cruz. 2006;101:869-74

23. Fraiha H, Ward RD, Shaw JJ, Lainson R. Fauna antropófila de flebótomos da rodovia transamazônica, Brasil (Diptera: Psychodidae). Bol Of Sanit Panam. 1978; 84:134-9.

24. Lainson R, Shaw JJ. Leishmaniasis in the New World. In: Collier L, Balows A, Sussman M. eds. Topley \& Wilson's Microbiology and Microbial Infections, Parasitology. London: Arnold; 2005. p. 313-49.

25. Oliveira AG, Galati, EAB, Fernandes CE, Dorval MEC, Brazil RP. Seasonal variation of Lutzomyia longipalpis (lutz \& neiva, 1912) (diptera: psychodidae: phlebotominae) in endemic area of visceral leishmaniasis, Campo Grande, state of Mato Grosso do Sul, Brazil. Acta Trop. 2008;105:55-61.

26. Casaril AE, Manaco NZN, Oliveira EF, Eguchi GU, Paranhos-Filho AC, Pereira LE, et al. Spatiotemporal analysis of sandfly fauna (Diptera: Psychodidae) in an endemic area of visceral leishmaniasis at Pantanal, central South America. Parasit Vectors. $2014 ; 7: 364$

27. Fernandes EFL, Anunciação VS. Impactos de eventos climáticos extremos e seus reflexos na cidade de Aquidauana-MS. Rev. Geonorte(Ed. Esp.). 2012;1:707-20.

28. Instituto Brasileiro de Geografia e Estatística (IBGE). Cidades@ [Internet]. Aquidauana: IBGE. [cited 2013 Sep 25]. Available from: http://cidades.ibge.gov.br/ xtras/perfil.php?codmun $=500110$.

29. Zaroni MJ, Amaral FCS, Silva EF, Coelho MR, Carvalho-Jr W, et al. Zoneamento Agroecológico do Município de Aquidauana - MS, Boletim de Pesquisa e Desenvolvimento / Embrapa Solos. Rio de Janeiro: Embrapa Solos; 2011.

30. Galati EAB. Phlebotominae (Diptera, Psychodidae) classificação, morfologia, terminologia e identificação de adultos. Departamento de Epidemiologia Faculdade de Saúde Pública. Apostila Disciplina HEP 5752 Bioecologia e Identificação de Phlebotominae 2014 [Internet]. Universidade de São Paulo; [cited 2011 Dec 28]. Available from: http://www.fsp.usp.br/egalati/ApostilaPhlebotominae_2014_vol_I.pdf. 
Figueiredo HR, Santos MFC, Casaril AE, Infran JOM, Ribeiro LM, Fernandes CES, Oliveira AG. Sand flies (Diptera:Psychodidae) in an endemic area of leishmaniasis in Aquidauana municipality, Pantanal of Mato Grosso do Sul, Brazil. Rev Inst Med Trop Sao Paulo. 2016;58:87.

31. Marcondes CB. A proposal of generic and subgeneric abbreviations of phlebotomine sandflies (Diptera: Psychodidae: Phlebotominae) of the world. Entomol News. 2007;118:351-6.

32. El Tai NO, Osman OF, El Fari M, Presber WH, Schonian G. Genetic heterogenecity of ribossomal internal transcribed spacer in clinical samples of Leishmania donovani spotted on filter paper as revealed by single-strand conformation polymorphisms and sequencing. Trans R Soc Trop Med Hyg. 2000;94:575-9.

33. Roberts DR, Hsi BP. An index of species abundance for use with mosquito surveillance data. Environ Entomol. 1979;8:1007-13.

34. Margalef R. La teoría de la información en ecología. Memórias de la Real Academia de Ciencias y Artes de Barcelona. 1957;32:373-449.

35. Hayek LAC, Buzas MA. Surveying natural populations. New York: Columbia University Press; 1997.

36. Galati EAB, Nunes VLB, Rego-Junior FA, Oshiro ET, Chang MR. Estudo de flebotomíneos (Diptera: Psychodidae) em foco de leishmaniose visceral no Estado de Mato Grosso do Sul, Brasil. Rev Saude Publica. 1997;31:378-90.

37. Oliveira AG, Andrade-Filho JD, Falcão AL, Brazil RP. Estudo de flebotomíneos (Diptera, Psychodidae, Phlebotominae) na zona urbana da cidade de Campo Grande, Mato Grosso do Sul, Brasil, 1999-2000. Cad Saude Publica. 2003;19:933-44.

38. Ximenes MFFM, Souza MF, Castellón EC. Density of sand flies (Diptera: Psychodidae) in domestic end wild animal shelters in an area of visceral leishmaniasis in the state of Rio Grande do Norte, Brazil. Mem Inst Osvaldo Cruz. 1999;94:427-32.

39. Flórez M, Martínez JP, Guitierrez R, Luna KP, Serrano VH, Ferro C, et al. Lutzomyia longipalpis (Diptera: Psychodidae) en un foco suburbano de leishmaniosis visceral en el Canón del Chicamocha en Santander, Colombia. Biomedica, 2006; 26(Supl. 1):109-20.

40. Cabrera OL, Mosquera L, Santamaría E. Flebótomos (Diptera: Psychodidae) del departamento de Guaviare, Colombia, con nuevos registros para el país. Biomédica 2009;29:73-86

41. Galati EAB, Marassá AM, Fonsceca MB, Gonçalves-Andrade RM, Consales CA, Bueno EFM. Phlebotomines (Diptera, Psychodidae) in the speleological province of the Ribeira Valley: 3. Serra district - area of hostels for tourists who visit the Parque Estadual do Alto Ribeira (PETAR), state of São Paulo, Brazil. Rev Bras Entomol. 2010; 54:665-76

42. Moschin JC, Ovallos FG, Sei IA, Galati EAB. Ecological aspects of phlebotomine fauna (Diptera, Psychodidae) of Serra da Cantareira, Greater São Paulo Metropolitan region, state of São Paulo, Brazil. Rev Bras Epidemiol. 2013;16:190-201.

43. Silva DF, Freitas RA., Franco AMR. Diversidade e abundância de flebotomíneos do gênero Lutzomyia (Diptera: Psychodidae) em áreas de mata do nordeste de Manacapuru, AM. Neotrop Entomol. 2008;36:38-44.

44. Alvez GB, Oshiro, ET, Leite MC, Melão AV, Ribeiro LM, Mateus NLF, et al. Phlebotomine sandflies fauna (Diptera: Psychodidae) at rural settlements in the municipality of Cáceres, State of Mato Grosso, Brazil. Rev Soc Bras Med Trop. 2012; 45:437-43.

45. Barata RA, França-Silva JC, Mayrink W, Silva JC, Prata A, Lorosa ES, et al. Aspectos da ecologia e do comportamento de flebotomíneos em área endêmica de leishmaniose visceral, Minas Gerais. Rev Soc Bras Med Trop. 2005;38:421-25.

46. Costa CHN, Tapety CMM, Werneck GL. Controle da leishmaniose visceral em meio urbano: estudo de intervenção randomizado fatorial. Rev Soc Bras Med Trop. 2007;40:415-19.

47. Forattini OP. Novas observaçoes sobre a biologia de fleb6tomos em condiçoes naturais (Diptera, Psychodidae). Arq Fac Hig Saude Publica Univ Sao Paulo. 1960; 85:209-15.
48. Rangel EF, Vilela ML. Lutzomyia longipalpis (Diptera, Psychodidae, Phlebotominae) e urbanização da leishmaniose visceral no Brasil. Cad Saude Publica. 2008;24:294852 .

49. Peroni N, Hernández MIM. Ecologia de populações e comunidades. Florianópolis:UFSC; 2011.

50. Ricklefs RE. A economia da natureza. $6^{\mathrm{a}}$ ed. Rio de Janeiro: Ed. Guanabara Koogan; 2010 .

51. Gomes AC. Mecanismos e significado epidemiológico da domiciliação. Rev Saude Publica. 1986;20:385-90.

52. Dias FOP, Lorosa ES, Rebêlo JMM. Fonte alimentar sanguínea e a peridomiciliação de Lutzomyia longipalpis (Lutz \& Neiva, 1912) (Psychodidae, Phlebotominae). Cad Saude Publica. 2003;19:1373-80.

53. Maia-Elkhoury ANS, Alves WA, Sousa-Gomes ML, Sena JM, Luna EA. Visceral leishmaniasis in Brazil: trends and challenges. Cad Saude Pública. 2008;24:2941-47.

54. Nunes VLB, Galati EAB, Cardozo C, Rocca MEG, Andrade ARO, Santos MFC, et al. Estudo de flebotomíneos (Diptera, Psychodidae) em área urbana do município de Bonito, Mato Grosso do Sul, Brasil. Rev Bras Entomol. 2008;52:446-51.

55. Oliveira EF, Silva EA, Fernandes CES, Paranhos-Filho AC, Gamarra, RM, Ribeiro AA, et al. Biotic-factors and occurrence of Lutzomyia longipalpis in endemic área of visceral leishmaniasis, Mato Grosso do Sul, Brazil. Mem Inst Oswaldo Cruz. 2012b; 101:396-401.

56. Oliveira EF, Fernandes CES, Silva EA, Brazil RP, Oliveira AG. Climatic factors an population density of Lutzomyia longipalpis (Lutz \& Neiva, 1912) in an urban endemic area of visceral leishmaniasis in midwest Brazil. J Vector Ecol. 2013;38:224-8.

57. Queiroz MFM, Varjão JR, Moraes SC, Salcedo GE. Analysis of sandflies (Diptera: Psychodidae) in Barra do Garças, state of Mato Grosso, Brazil, and the influence of environmental variables on the vector density of Lutzomyia longipalpis(Lutz \& Neiva, 1912). Rev Soc. Bras Med Trop. 2013;45:313-7.

58. Rêgo FD, Shimabukuro PHF, Quaresma PF, Coelho IR, Tonelli GB, Silva KMS, et al. Ecological aspects of the Phlebotominae fauna (Diptera: Psychodidae) in the Xakriabá Indigenous Reserve, Brazil. Parasit Vectors. 2014;7:220.

59. Lainson R, Rangel EF. Lutzomyia longipalpis e a eco-epidemiologia da leishmaniose visceral americana (LVA) no Brasil. In: Rangel EF, Lainson R. orgs. Flebotomíneos do Brasil. Rio de Janeiro: Fiocruz; 2003. p. 311-326.

60. Marcondes M, Rossi CN. Leishmaniose visceral no Brasil. Braz J Vet Res Anim Sci 2013;50:341-52.

61. Monteiro EM, Silva JCF, Costa RT, Costa DC, Barata RA, Paula EV, et al Leishmaniose visceral: estudo de flebotomíneos e infecção canina em Montes Claros, Minas Gerais. Rev Soc Bras Med Trop. 2005;38:147-52.

62. Santos SO, Andrade-Filho JD, Honer MR. Lutzomyia aldafalcaoae sp. n. a new species of Phlebotominae (Diptera: Psychodidae) from Mato Grosso do Sul, Brazil. Mem Inst Oswaldo Cruz. 2001; 96:791-4.

63. Braga-Miranda LC, Miranda M, Galati EAB. Phlebotomine fauna in a rural area of the Brazilian Pantanal. Rev Saude Publica. 2006;40:324-6.

64. Dorval ME, Cristaldo G, Rocha HC, Alves TP, Alves MA, Oshiro ET, et al Phlebotomine fauna (Diptera: Psychodidae) of an American cutaneous leishmaniasis endemic area in the state of Mato Grosso do Sul, Brazil. Mem Inst. Oswaldo Cruz. 2009;104:695-702.

65. Guimarães VCFV, Costa PL, Silva FJ, Silva KT, Silva KG, Araújo AIF, et al Phlebotomine sandflies (Diptera: Psychodidae) in São Vicente Férrer, a sympatric area to cutaneous and visceral leishmaniasis in the state of Pernambuco, Brazil. Rev Soc Bras Med Trop. 2012;45:66-70. 
Figueiredo HR, Santos MFC, Casaril AE, Infran JOM, Ribeiro LM, Fernandes CES, Oliveira AG. Sand flies (Diptera:Psychodidae) in an endemic area of leishmaniasis in Aquidauana municipality, Pantanal of Mato Grosso do Sul, Brazil. Rev Inst Med Trop Sao Paulo. 2016;58:87.

66. Pinheiro MPG, Silva JHT, Cavalcanti KB, Azevedo PRM, Ximenes MFFM. Ecological interactions among phlebotomines (Diptera: Psychodidae) in an agroforestry environment of northeast Brazil. J Vector Ecol. 2013;38:307-16.

67. Rangel EF, Lainson R. Proven and putative vectors of American cutaneous leishmaniasis in Brazil: aspects of their biology and vectorial competence. Mem Inst Oswaldo Cruz. 2009; 104:937-54.

68. Vilela ML, Azevedo CG, Carvalho BM, Rangel EF. Phlebotomine fauna (Diptera: Psychodidae) and putative vectors of leishmaniases in impacted area by hydroelectric plant, state of Tocantins, Brazil. PLoS ONE. 2011;6:1-7.

69. Nieves E, Oraá L, Rondón Y, Sánchez M, Sánchez Y, Rojas M, et al. Effect of environmental disturbance on the population of sandflies and Leishmania transmission in an endemic area of Venezuela. J Trop Med. 2014;2014:2-7.

70. Saraiva L, Carvalho GML, Gontijo CMF, Quaresma PF, Lima ACVMR. et al. Natural Infection of Lutzomyia neivai and Lutzomyia sallesi (Diptera: Psychodidae) by Leishmania infantum chagasi in Brazil. J Med Entomol. 2009;46:1159-63.

71. Silva REA, Andreotti R, Honer MR. Comportamento de Lutzomyia longipalpis, vetor principal da leishmaniose visceral americana, em Campo Grande, Estado do Mato Grosso do Sul. Rev Soc Bras Med Trop. 2007;40:420-5.

72. Brazil RP. The dispersion of Lutzomyia longipalpis in urban áreas. Rev Soc Bras Med Trop. 2013;46:263-4.

73. Desjeux P. The increase in risk factors for leishmaniasis worldwide. Trans R Soc Trop Med Hyg. 2001;95:239-43

74. Ximenes MFF, Silva VPM, Queiroz PVS, Rego M, Cortez ALM, Batista LMM, et al. Flebotomíneos (Diptera: Psychodidae) e leishmanioses no Rio Grande do Norte, nordeste do Brasil: reflexos do ambiente antrópico. Neotrop Entomol. 2007;36:128 37.

75. Afonso MMS, Duarte, R, Miranda JC, Caranha L, Rangel EF. Studies on the feeding habits of Lutzomyia (Lutzomyia) longipalpis (Lutz \& Neiva, 1912) (Diptera: Psychodidae: Phlebotominae) populations from endemic areas of American visceral leishmaniasis in Northeastern Brazil. J Trop Med. 2012;2012:1-5.

76. Baum M, Ribeiro MCV, Lorosa ES, Damasio GAC, Castro EA. Eclectic feeding behavior of Lutzomyia (Nyssomyia) intermedia (Diptera, Psychodidae, Phlebotominae) in the transmission area of American cutaneous leishmaniasis, state of Paraná, Brazil. Rev Soc Bras Med Trop. 2013;46:560-5.

77. Muniz LHG, Rossi RM, Neitzke HC, Monteiro WM, Teodoro U. Estudo dos hábitos alimentares de flebotomíneos em área rural no sul do Brasil. Rev Saude Publica. 2006 40:1087-93.

78. Domingues MF, Carreri-Bruno GC, Ciaravolo RMC, Galati EAB, Wanderley DMV, Corrêa FMA. Leishmaniose tegumentar americana: flebotomíneos de área de transmissão, no município de Pedro de Toledo, região sul do Estado de São Paulo, Brasil. Rev Soc Bras Med Trop. 1998;31:425-32.

79. Jones TM, Quinnell R. Testing predictions for the evolution of lekking in the sandfly, Lutzomyia longipalpis. Anim Behav. 2002;63:605-12.

80. Quinnell RJ, Dye C. An experimental study of the peridomestic distribution of Lutzomyia longipalpis (Diptera:Psychodidae). Bull Entomol Res. 1994;84:379-82.

81. Kelly DW, Dye C. Pheromones, kairomones and the aggregation dynamics of the sandfly Lutzomyia longipalpis. Anim Behav. 1997;53:721-31.

82. Spiegel CN, Batista-Pereira LG, Bretas JAC, Eiras AE, Hooper AM, Peixoto AA, et al. Pheromone gland development and pheromone production in Lutzomyia longipalpis (Diptera: Psychodidae: Phlebotominae). J Med Entomol. 2011;48:489-95.
83. Dye C, Davies CR, Lainson R. Communication among phlebotomine sandflies: a field study of domesticated Lutzomyia longipalpis populations in Amazonian Brazil. Anim Behav. 1991;42:183-92.

84. Hamilton JGC, Maingon RDC, Alexander B, Ward RD, Brazil RP. Analysis of the sex pheromone extract of individual male Lutzomyia longipalpis sandflies from six regions in Brazil. Med Vet Entomol. 2005;19:480-8.

85. Hamilton JGC. Sandfly pheromones. Their biology and potential for use in control programs. Parasite. 2008;15:252-6.

86. Carrasco J, Morrison A, Ponce C. Behaviour of Lutzomyia longipalpis in na area of southern Honduras endemic for visceral/atypical cutaneous leishmaniasis. An Med Trop Parasitol. 1998;92:869-76.

87. Resende MC, Camargo MCV, Vieira JRM, Nobi RCA, Porto NMN, Oliveira CL, et al. Seasonal variation of Lutzomyia longipalpis in Belo Horizonte, state of Minas Gerais. Rev Soc Bras Med Trop. 2006;39:51-5

88. Alexander B, Carvalho RL, McCallum H, Pereira MH. Role of the domestic chicken (Gallus gallus) in the epidemiology of urban visceral leishmaniasis in Brazil. Emerg Infect Dis. 2002;8:1480-5.

89. Araújo JC, Rebêlo JMM, Carvalho ML, Barros VLL. Composição dos flebotomíneos (Diptera, Psychodidae) do Município da Raposa- MA, Brasil. Área endêmica de leishmanioses. Entomol Vect. 2000;7:33-47.

90. Carvalho ML, Rebêlo JMM, Araújo J, Barros VLL. Aspectos ecológicos dos flebotomíneos (Díptera, Psychodidae) do município de São José de Ribamar, MA Brasil. Área endêmica de leishmanioses. Entomol Vect. 2000;7:19-32.

91. Forattini OP, Rabello EX, Galati EAB. Novos encontros de flebotomíneos no estado de São Saulo, Brasil, com especial referência à Lutzomyia longipalpis. Rev Saude Publica. 1976;10:125-8

92. Souza CM, Pessanha JE, Barata RA, Monteiro EM, Costa DC, Dias ES. Study on phlebotomine sand fly (Diptera: Psychodidae) fauna in Belo Horizonte, state of Minas Gerais, Brazil. Mem Inst Oswaldo Cruz. 2004;99:795-803

93. Teodoro U, Kühl JB, Santos DR, Santos ES. Impacto de alterações ambientais na ecologia de flebotomíneos no sul do Brasil. Cad Saude Publica. 1999;15:901-6.

94. Teodoro U, Silveira TGV, Santos DR, Santos ES, Santos AR, Olivira O, et al. Frequência da fauna de flebotomíneos no domicílio e em abrigos de animais domésticos no peridomicílio, nos Municípios de Cianorte e Doutor Camargo- Estado do Paraná- Brasil. Rev Patol Trop. 2001;30:209-23.

95. Cruz MRF, Galati EAB, Cruz CFR. Ecological aspects of the sandfly fauna (Diptera, Psychodidae) in an American cutaneous leishmaniasis endemic area under the influence of hydroelectric plants in Paranapanema river, State of Paraná, Brazil. Rev Soc Bras Med Trop. 2012;45:430-6.

96. Machado TO, Bragança MAL, Carvalho ML, Andrade- Filho JD, Species diversity of sandflies (Diptera: Psychodidae) during different seasons and in differen environments in the district of Taquaruçú, state of Tocantins, Brazil. Mem Inst Osvaldo Cruz. 2012;107:955-9.

97. Aguiar GM, Vilela ML, Lima RB. Ecology of the sandflies of Itaguai, na area of cutaneous leishmaniasis in the state of Rio de Janeiro:food preferences (Diptera, Psychodidae, Phlebotominae). Mem Inst Oswaldo Cruz. 1987;82:583-4.

98. Missawa NA, Lorosa ES, Dias ES. Preferência alimentar de Lutzomyia longipalpis (Lutz \& Neiva, 1912) em área de transmissão de leishmaniose visceral em Mato Grosso. Rev Soc Bras Med Trop. 2008;41:365-8.

99. Morrison AC, Ferro C, Morales A, Tesh RB, Wilson ML. Dispersal of the sand fly Lutzomya longipalpis (Diptera: Psychodidae) at an endemic focus of visceral leishmaniasis in Colombia. J Med Entomol. 1993;30:427-35. 
Figueiredo HR, Santos MFC, Casaril AE, Infran JOM, Ribeiro LM, Fernandes CES, Oliveira AG. Sand flies (Diptera:Psychodidae) in an endemic area of leishmaniasis in Aquidauana municipality, Pantanal of Mato Grosso do Sul, Brazil. Rev Inst Med Trop Sao Paulo. 2016;58:87.

100. Carvalho MSL, Bredt A, Maneghin ERS, Oliveira C. Flebotomíneos (Diptera: Psychodidae) em áreas de ocorrência de leishmaniose tegumentar americana no Distrito Federal, Brasil, 2006 a 2008. Epidemiol Serv Saude. 2010;19:227-37.

101. Miranda JC, Reis E, Schriefer A, Gonçalves M, Reis MG, Carvalho L, et al. Frequency of infection of Lutzomyia phlebotomines with Leishmania braziliensis in a Brazilian endemic area as assessed by pinpoint capture and polymerase chain reaction. Mem Inst Oswaldo Cruz. 2002;97:185-8.

102. Oliveira-Pereira YN, Rabêlo JMM, Moraes JLP, Pereira SRF. Diagnóstico molecular da taxa de infecção natural de flebotomíneos (Psychodidae, Lutzomyia) por Leishmania sp na Amazônia maranhense. Rev Soc Bras Med Trop. 2006;39:540-3.

103. Missawa NA, Michalsky EM, Fortes- Dias CL, Dias ES. Lutzomyia longipalpis naturally infected by Leishmania (L.) chagasi in Várzea Grande, Mato Grosso State, Brazil, an area of intense transmission of visceral leishmaniasis. Cad Saude Publica. 2010;26:2414-9.

104. Pita-Pereira D, Cardoso MAB, Alves CR, Brazil RP, Britto C. Detection of natural infection in Lutzomyia cruzi and Lutzomyia forattinii (Diptera: Psychodidae: Phlebotominae) by Leishmania infantum chagasi in an endemic area of visceral leishmaniasis in Brazil using a PCR multiplex assay. Acta Trop. 2008;107:66-9.
105. Pita-Pereira D, Alves CR, Souza MB, Brazil RP, Bertho AL, Barbosa AF, et al Identification of naturally infected Lutzomyia intermedia and Lutzomyia migonei with Leishmania (Viannia) braziliensis in Rio de Janeiro (Brazil) revealed by a PCR multiplex non-isotopic hybridization assay. Trans R Soc Trop Med Hyg. 2005;99:90513.

106. Dávila AMR, Momen H. Internal-transcribed-spacer (ITS) sequences used to explore phylogenetic relationships within Leishmania. Ann Trop Med Parasitol. 2000; 94:6514.

107. Marfurt J, Nasereddin A, Niederwieser I, Jaffe CL, Beck HP, Felger I. Identification and differentiation of Leishmania species in clinical samples by PCR amplification of the miniexon sequence and subsequent restriction fragment length polymorphism analysis. J Clin Microbiol. 2003;41:3147-53.

108. Soares MRA, Carvalho CC, Silva LA, Lima MSCS, Barral AMP, Rebêlo JMM, et al. Análise molecular da infecção natural de Lutzomyia longipalpis em área endêmica de leishmaniose visceral no Brasil. Cad Saude Publica. 2010;26:2409-13.

109. Secretaria de Saúde do Estado de Mato Grosso do Sul. Relatório de notificações de leishmaniose visceral canina. Campo Grande: Governo do Estado de Mato Grosso do Sul; 2014.

Received: 01 September 2015

Accepted: 25 July 2016 